\title{
PENGEMBANGAN DAYA TARIK WISATA BERBASIS EKOWISATA DI GUNUNG PUTRI LEMBANG KABUPATEN BANDUNG BARAT
}

\author{
Rieke Sri Rizki A ${ }^{1}$ \\ DOSEN STIEPAR YAPARI BANDUNG \\ Rsrak17@yahoo.com \\ Septa Setiawan ${ }^{2}$ \\ MAHASISWA STIEPAR YAPARI BANDUNG \\ Septasetiawan3@gmail.com
}

\begin{abstract}
ABSTRAK
Tujuan penelitian yaitu mengetahui pengembangan daya tarik wisata berbasis ekowisata di Gunung Putri Lembang Kabupaten Bandung Barat. Penelitian ini menggunakan metode analisis data deskriptif kualitatif dan pengumpulan data menggunakan teknik observasi, wawancara mendalam dan dokumentasi.Hasil penelitian menunjukan bahwa gunung putri adalah tempat yang berpotensi untuk di kembangkan menjadi wisata berbasis ekowisata. Gunung putri memiliki tempat yang dapat di kembangkan dalam konsep ekowisata seperti area camping, area hiking dan area offroad serta memiliki tempat bersejarah dari peninggalan terdahulu yaitu benteng Belanda. Pendidikan di dalam unsur ekowisata belum di terapkan oleh pengelola serta kurangnya kesadaran wisatawan dan masyarakat dalam menjaga dan melestarikan lingkungan sekitar. Namun di samping itu sudah terjadinya keterlibatan masyarakat lokal di dalam pengelolaan daya tarik gunung putri. Berdasarkan hasil penelitian, dapat disimpulkan bahwa konsep ekowisata dapat mengembangkan daya tarik di gunung putri yang melibatkan wisatawan, industri pariwisata, pemerintah, masyarakat lokal dan lembaga masyarakat.
\end{abstract}

Kata kunci : Konsep Ekowisata, Meningkatkan Pendapatan, Keterlibatan Pengembangan Ekowisata 


\title{
DEVELOPMENT OF ECOTOURISM BASED AT GUNUNG PUTRI LEMBANG IN BANDUNG BARAT REGENCY
}

\begin{abstract}
The purpose of research is to know the development of ecotourism based tourism attraction in Gunung Putri Lembang West Bandung regency. This research uses descriptive qualitative data analysis methods and data collection using observation techniques, in-depth interviews and documentation. The results showed that the mountain princess is a place that has the potential to be developed into ecotourism-based tourism. Gunung putri has a place that can be developed in the concept of ecotourism such as camping areas, hiking areas and offroad areas and has a historic place from the previous relics of the Dutch fort. Education in the element of ecotourism has not been applied by the manager and the lack of awareness of tourists and the community in maintaining and preserving the surrounding environment. But in addition there has been the involvement of local communities in the management of the appeal of the Gunung Putri. Based on the results of the research, it can be concluded that the concept of ecotourism can develop a fascination in the mountain of women involving tourists, the tourism industry, government, local communities and community institutions.
\end{abstract}

Keywords: Ecotourism Concept, Increasing Revenue, Ecotourism Development Engagement

\section{PENDAHULUAN}

Sektor Pariwisata sebagai kegiatan perekonomian telah menjadi andalan dan prioritas pengembangan bagi sejumlah Negara, terlebih bagi Negara berkembang seperti Indonesia. Indonesia memiliki potensi wilayah yang luas dengan adanya daya tarik wisata cukup besar, banyaknya keindahan alam, aneka warisan sejarah budaya dan kehidupan masyarakat. Setiap daerah di Indonesia memiliki keindahannya maupun adat istiadat yang ada di daerah tersebut sehingga menarik minat wisatawan untuk mengunjunginya. Untuk meningkatkan peran kepariwisataan, dibutuhkan antara lain atraksi obyek wisata sendiri yang dapat dijual dengan sarana dan prasarana yang mendukungnya yang terkait dalam industri pariwisata. Usaha untuk mengembangkan daerah tujuan wisata harus memperhatikan berbagai faktor yang berpengaruh terhadap keberadaan suatu daerah tujuan wisata.

Kabupaten Bandung Barat memiliki berbagai macam obyek wisata diantaranya wisata alam, wisata buatan dan wisata sejarah. Apabila dikelola dan dikembangkan dengan baik dan tepat maka akan menjadi daerah tujuan wisata yang menarik untuk dikunjungi. Selain itu, dengan meningkatnya wisatawan yang berkunjung maka pariwisata juga merupakan komoditas yang dibutuhkan oleh setiap individu.

Di Kabupaten Bandung Barat Kecamatan Lembang Desa Jayagiri terdapat sebuah Gunung yang terkenal di dengan berlegendakan Sangkuriang yaitu Gunung 
Tangkuban Parahu. Namun ada juga sebuah Gunung yang terkait dari legenda tersebut dan belum banyak dikenal oleh wisatawan yaitu Gunung Putri. Gunung Putri berada diketinggian sekitar 1.587 meter diatas permukaan laut (mdpl). Dengan panorama alam yang indah serta udaranya yang sejuk, wisatawan dapat memanjakan dengan disuguhkan moment sunrise secara langsung dari bukit Gunung Putri tersebut dengan berlatar belakang Kota Bandung. Gunung Putri Berada di kawasan strategis diantara kawasan hutan Perum Perhutani RPH Lembang, BKPH Lembang, KPH Bandung Utara tepatnya berada di Kampung Gunung Putri Desa Jayagiri Kecamatan Lembang Kabupaten Bandung Barat.

\section{Daya Tarik Wisata}

Daya Tarik Wisata adalah segala sesuatu yang menyebabkan wisatawan untuk : melihat, melakukan, mencicipi, datang dan membeli. Menurut Warpani (2007:31) Daya tarik wisata, yaitu segala sesuatu yang menjadi penyebab wisatawan mengunjungi suatu daerah tertentu. Daya tarik wisata yang ada di suatu (DTW), dapat berupa objek alamiah maupun buatan. Menurut Warpani (2007:45) Daya tarik wisata yang dimiliki suatu destinasi pariwisata atau daerah tujuan wisata (DTW) yakni sesuatu yang dapat dilihat, misalnya pemandangan alam, peninggalan purbakala, pertunjukan; atau sesuatu yang dapat dilakukan, misalnya rekreasi, olahraga, meneliti, atau sesuatu yang dapat dibeli. Yakni barang-barang unik atau cendramata-cendramata.

\section{Faktor Pendorong Pengembangan Objek Wisata}

Menurut Setianingsih (2006:39), menjelaskan bahwa faktor pendorong adalah hal atau kondisi yang dapat mendorong atau menumbuhkan suatu kegiatan, usaha atau produksi (Kamus Besar Bahasa Indonesia Online). Menurut Soekadijo dalam Setianingsih (2006:39) modal atraksi yang menarik kedatangan wisatawan ada tiga diantaranya :

a. Modal dan potensi alam, alam merupakan salah satu faktor pendorong seorang melakukan perjalanan wisata karena ada orang berwisata hanya sekedar menikmati keindahan alam, ketenangan alam, serta ingin menikmati keaslian fisik, flora dan faunanya.

b. Modal dan potensi kebudayaannnya. Yang dimaksud potensi kebudayaan disini merupakan kebudayaan dalam arti luas bukan hanya meliputi seperti kesenian atau kehidupan keratin dll.

c. Modal dan potensi manusia. Manusia dapat dijadikan atraksi wisata yang berupa keunikan-keunikan adat istiadat maupun kehidupannya namun jangan sampai martabat dari manusia tersebut direndahkan sehingga kehilangan martabatnya sebagai manusia

\section{Ekowisata}

Menurut Hakim (2004) Ekowisata adalah perjalanan wisata ke suatu lingkungan baik alam yang alami ataupun buatan serta budaya yang ada yang bersifat informatif dan partisipatif yang bertujuan untuk menjamin kelestarian alam dan sosial-budaya. Ekowisata menitikberatkan pada tiga hal utama yaitu keberlangsungan alam atau ekologi, memberi manfaat ekonomi dan secara psikologis dapat diterima dalam kehidupan social masyarakat. 


\section{Aspek - Aspek Ekowisata}

Menurut Iwan Nugroho dalam Buku Ekowisata dan Pembangunan Berkelanjutan (2011:1) bahwa Pembangunan Pariwisata memiliki peran signifikan dalam aspek ekonomi, sosial dan lingkungan. Dalam aspek ekonomi, sektor pariwisata mengkontribusi devisa dari kunjungan wisatawan manca negara (wisman) dan Produk Domestik Bruto (PDB) beserta komponen - komponennya. Dalam aspek sosial, pariwisata berperan dalam penyerapan tenaga kerja, apresiasi seni, tradisi dan budaya bangsa, dan peningkatan jati diri bangsa. Dalam aspek lingkungan, pariwisata khususnya ekowisata dapat mengangkat produk dan jasa wisata seperti kekayaan keunikan alam dan laut, dan alat yang efektif bagi pelestarian lingkungan alam dan seni budaya tradisional.

\section{Prinsip - prinsip Ekowisata}

Menurut Peraturan Menteri Dalam Negeri Nomor 33 Tahun 2009 Pasal 3 terdapat prinsip pengembangan ekowisata meliputi:

a. Kesesuaian antara jenis dan karakteristik ekowisata

b. Konservasi, yaitu melindungi, mengawetkan, dan memanfaatkan secara lestari sumber daya alam yang digunakan untuk ekowisata

c. Ekonomis, yaitu memberikan manfaat untuk masyarakat setempat dan menjadi penggerak pembangunan ekonomi di wilayahnya serta memastikan usaha ekowisata dapat berkelanjutan

d. Edukasi, yaitu mengandung unsur pendidikan untuk mengubah persepsi seseorang agar memiliki kepedulian, tanggung jawab, dan komitmen terhadap pelestarian lingkungan dan budaya

e. Memberikan kepuasan dan pengalaman kepada pengunjung

f. Partisipasi masyarakat, yaitu peran serta masyarakat dalam kegiatan perencanaan, pemanfaatan, dan pengendalian ekowisata dengan menghormati nilai-nilai sosial-budaya dan keagamaan masyarakat di sekitar kawasan

g. Menampung kearifan lokal

\section{Unsur - Unsur Pengembangan Ekowisata}

Menurut Yoeti (2008:196), mengandung empat unsur utama yang dianggap paling penting dalam pengembangan Ekowisata yaitu

a. Terdapat unsur pro-aktif yaitu sebuah sikap seseorang yang mampu mengenali kesempatan dan memanfaatkanmya sehingga menghasilkan perubahan ke arah yang lebih baik. Orang dengan sikap yang proaktif tidak sekedar bereaksi terhadap berbagai keadaan tetapi memiliki inisiatif untuk melakukan aksi terhadap perubahan.

b. Ada kepedulian terhadap pelestarian lingkungan hidup yaitu dengan menjaganya serta melestarikan di lingkungan sekitar. Berfungi pagi keberlangsungan ekosistem yang terjadi di daerah tersebut.

c. Adanya keterlibatan penduduk lokal, dengan mengajak masyarakat sekitar untuk terlibat di dalam pemeliharan serta menjaga lingkungan sekitar serta dengan keterlibatan masyarakat pula akan menghasilkan kesejahteraan mayarakat sekitar terwujud.

d. Adanya Unsur Pendidikan, Ekowisata meningkatkan kesadaran dan apresiasi terhadap alam, nilai-nilai peninggalan sejarah dan budaya. Ekowisata memberikan nilai tambah kepada pengunjung dan masyarakat dalam bentuk 
pengetahuan dan pengalaman. Nilai tambah ini mempengaruhi perubahan perilaku dari pengunjung, masyarakat dan pengembang pariwisata agar sadar dan lebih menghargai alam, nilai-nilai peninggalan sejarah dan budaya.

\section{Tujuan, Manfaat dan Sasaran Ekowisata}

Menurut Fandeli (2004) bahwa Ekowisata memiliki Tujuan, Manfaat dan Sasaran yaitu

\section{Tujuan}

a. Mendorong usaha pelestarian dan pembangunan berkelanjutan

b. Membangun kesadaran dan penghargaan atas lingkungan dan budaya di daerah tujuan wisata, baik bagi diri wisatawan, masyarakat setempat maupun para penentu kebijakan di bidang kebudayaan dan kepariwisataan setempat

c. Mengurangi dampak negatif berupa kerusakan atau pencemaran lingkungan dan budaya lokal akibat kegiatan wisata

\section{Manfaat}

a. Mendidik wisatawan tentang fungsi dan manfaat lingkungan, alam dan budaya

b. Meningkatkan kesadaran dan penghargaan akan lingkungan dan budaya sambil memperkecil dampak kegiatan manusia terhadap lingkungan tersebut

c. Bermanfaat secara ekologi, sosial, ekonomi bagi masyarakat setempat

\section{Sasaran}

a. Terwujudnya kesadaran antara wisatawan dengan masyarakat setempat tentang konservasi

b. Terwujudnya saling pengertian diantara wisatawan dan masyarakat setempat dalam menata, mengembangkan potensi ekowisata berdasarkan kepada pengalaman dan tukar pikiran tentang budaya, pengalaman hidup dan caracara konservasi alam diantara mereka, sehingga menghasilkan satu product positioning yang tepat

c. Terwujudnya organisasi masyarakat setempat yang bertujuan mengelola usaha pariwisata guna menunjang kebutuhan wisatawan selama berada di lokasi ekowisata dan dalam rangka mengembangkan hubungan dengan berbagai organisasi ekowisata nasional maupun internasional

Kerangka dasar pemikiran digunakan sebagai dasar atau landasan dalam pengembangan berbagai konsep dan teori yang digunakan dalam penelitian ini maka dapat dirumuskan rencana strategis yang nantinya akan dijadikan pedoman kedepan. 


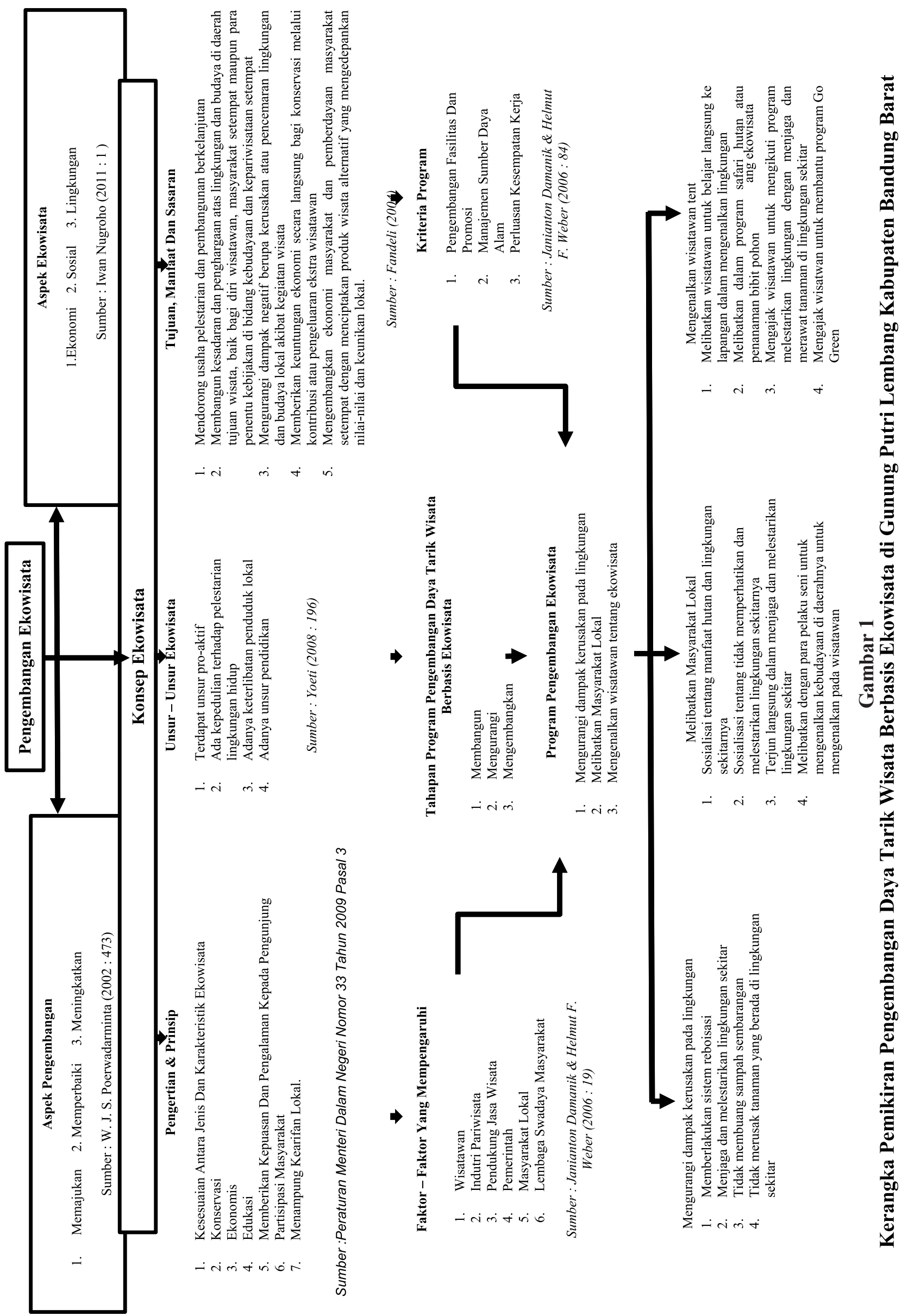




\section{METODOLOGI}

Metode yang digunakan dalam penelitian ini adalah metode deskriptif kualitatif. Penelitian ini dilakukan pada kondisi yang alamiah (natural setting). Peneliti menganalisis dan mendeskripsikan data dan informasi terkait dengan pengembangan daya tarik berbasis ekowisata di Gunung Putri Lembang Kabupaten Bandung Barat, dilakukan oleh peneliti secara sistematis dan lengkap melalui observasi, wawancara, dan studi dokumentasi. Dengan observasi diharapkan dapat mengetahui secara langsung bagaimana gambaran (1) pengembangan daya tarik wisata berbasis ekowisata di Gunung Putri Lembang Kabupaten Bandung Barat dan (2) faktor pendukung dan penghambat dalam pengembangan ekowisata Gunung Putri Lembang Kabupaten Bandung Barat Penelitian ini dilakukan pada kondisi yang alamiah (natural setting) artinya sesuai dengan kondisi yang ada di Gunung Putri Lembang Kabupaten Bandung Barat. Peneliti langsung menuju ke sumber data. Untuk mendapatkan data yang dibutuhkan, maka digunakan teknik trianggulasi. Bungin dalam Sugiyono (2007:203) menyatakan bahwa: "teknik ini lebih banyak menggunakan metode alam level mikro, seperti bagaimana mengumpulkan data dan analisis data sekaligus dalam sebuah penelitian, termasuk menggunakan informan sebagai alat uji keabsahan dan analisis hasil penelitian".

Berdasarkan konsep di atas, maka penelitian ini menggunakan teknik pengumpulan data adalah observasi, wawancara, dan studi dokumentasi. Bungin dalam Sugiyono (2007:115) mengemukakan beberapa bentuk observasi yang dapat digunakan dalam penelitian kualitatif, yaitu "observasi partisipasi, observasi tidak terstruktur, dan observasi kelompok tidak terstruktur". Wawancara yang digunakan dalam penelitian kualitatif adalah wawancara mendalam (in-depth interview) adalah proses memperoleh keterangan untuk tujuan penelitian dengan cara tanya jawab sambil bertatap muka antara pewawancara dengan informan, tanpa menggunakan guide. Adapun butir instrumen wawancara dengan (1) Dinas Pariwisata dan Kebudayaan Kabupaten Bandung Barat, (2) Kepala Desa (3) Pengelola Perhutani (4) LMDH (Lembaga Masyarakat Desa Hutan) dan (5) Tokoh Masyarakat.

Menurut Kusmayadi (2004:20) sampel adalah bagian dari populasi yang dianggap mewakili karakteristik suatu populasi, seperti pengunjung atau wisatawan.

\section{HASIL DAN PEMBAHASAN}

Jawa Barat memiliki banyak tempat wisata yang dapat dijadikan tempat favorit. Di Kabupaten Bandung Barat Kususnya terdapat Kecamatan Lembang yang memiliki beberapa desa di dalamnya. Yaitu Desa Lembang yang berada di pusat kota, kemudian Desa Kayu Ambon, Desa Cibogo, Desa Cikahuripan dan Desa Jayagiri. Desa Jayagiri terdapat sebuah perkampungan yang bernama kampung Gunung Putri Lembang. Gunung Putri merupakan salah satu pegunungan indah yang ada di Bandung yang berlokasi di Lembang Kabupaten Bandung Barat. Gunung Putri baru satu tahun berjalan. Awalnya gunung tersebut di kelola oleh warga sekitar namun berhubung gunung tersebut berada di area Perhutani akhirnya dipegang langsung oleh pihak Perhutani. Seiring dengan berjalannya waktu tempat yang bernama Gunung Putri ini di kelola oleh pihak Perhutan dan lembaga dari masyarakat sekitar. 
Disisi keindahan alam yang dapat di lihat dari Gunung Putri, Gunung Putri pun menyimpan warisan budaya yaitu benteng Gunung Putri yang termasuk kedalam bangunan cagar budaya yang dilindungi oleh Undang-Undang nomor 11 tahun 2010 tentang cagar budaya. Sebuah benteng dengan peninggalan dari kolonial Belanda yang terletak di puncak Gunung Putri, Kecamatan Lembang. Benteng tersebut dibangun sekitar Tahun 1803.

Gunung Putri berada di ketinggian 1587 mdpl ( meter di atas permukaan laut ) tepatnya berada di RW 10 Desa Jayagiri Kecamatan Lembang Kabupaten Bandung Barat dan berada di kaki gunung Tangkuban Parahu. Penduduk di Desa Jayagiri berjumlah 18.075 jiwa. Sedangkan jumlah Penduduk di daerah Gunung Putri bejumlah 1.049 jiwa. Terdiri dari 590 berjenis kelamin Laki-Laki dan 520 berjenis kelamin Perempuan. Mayoritas penduduk Desa Jayagiri berasal dari kalangan 20\% Petani sayuran, 70\% Peternak sapi dan 10\% lain-lain. Desa Jayagiri berbatasan dengan Desa lainnya seperti Desa Cibogo, Desa Kayu Ambon, Desa Cikahuripan dan Desa Lembang.

\section{Pengembangan Gunung Putri}

Gunung Putri ini memiliki tempat dimana akan di kembangkan lagi untuk kedepannya. Yaitu :

\section{Camping Area \\ 2. Hiking Area \\ 3. Offroad Area}

Dalam segi fasilitas terdapat beberapa fasilitas yang kurang dan harus di tambah kembali. Berikut fasilitas yang ada di lokasi Gunung Putri :

1. Terdapat 4 toilet. 2 toilet terdapat di camping area dan 2 area terdapat di hiking area

2. Air bersih beberapa toren

3. Parkiran

4. Warung Makan

Demi mendukung terciptanya wisatawan semakin banyak dan semakin berkembang. Maka Pengelola berharap supaya dapat tambahan fasilitas seperti :

1. Tempat teduh atau canopy

2. Gazebo

3. Dan Fasilitas lainnya yang mendukung terciptanya kenyamanan bagi penunjung

Adapun Harga Tiket Masuk Hiking Sebesar Rp. 7.500 / Orang dan Camping Area sebesar Rp. 17.500 / Orang. Maksimal Hiking di beri waktu 5 jam dan untuk Camping Area 1 hari 1 malam.

Pemerintah melalui Desa Jayagiri dalam Pengembangannya dalam kedepannya akan membangun fasilitas berupa panggung untuk memberikan tanda selamat datang dengan di sambut oleh kesenian khas tradisional dari masyarakat daerah Gunung Putri Lembang. Dalam hal ini Pemerintah juga melibatkan para pelaku seni musik ataupun tarian, guna memperdayakan dari masyarakat sekitar dan dapat menjadikan masyarakat sejahtera .

Dalam hal promosi, pemerintah Desa Jayagiri membuat brosur sejumlah 2.000 buah kemudian rencana pembuatan paket wisata dan mempromosikannya melalui apikasi seperti facebook, instagram serta aplikasi lainnya. 
Pemerintah Desa Jayagiri sedang mengerjakan penataan tempat penjualan bagi masyarakat. Dalam hal ini pemerintah berharap masyarakat dapat menggunakan fasilitas tersebut untuk berjualan serta menambah perekonomian bagi mereka.

Dalam segi mengembangkan daya tarik wisata berbasis ekowisata di Gunung Putri Lembang, Pengelola Perhutani bersama LMDH (Lembaga Masyarakat Desa Hutan) juga menerapkan sistem Sapta Pesona diantaranya :

1. Aman

2. Tertib

3. Bersih

4. Sejuk

5. Indah

6. Ramah Tamah

7. Kenangan

Diharapkan dari menerapkan Sapta Pesona menjadikan Gunung Putri Lembang lebih berkembang lagi dan wisatawan merasakan hasil yang terapkan oleh pihak Desa Jayagiri, Pengelola Perhutani, Pengelola LMDH (Lembaga Masyarakat Desa Hutan), dan Masyarakat Sekitarnya.

\section{Ekowisata Gunung Putri}

Pengelola Perhutani bekerja dengan LMDH (Lembaga Masyarakat Desa Hutan) dalam mengelola Gunung Putri supaya terjaga kawasannya dengan membangun gerakan Konservasi PHBM (Pengelola Hutan Bersama Masyarakat), KTH (Kelompok Tani Hutan) Dengan cara menanam rumput di area bawah pohon sebagai penempatan lahan kosong di bawah pohon. Bagian ini dapat melibatkan dan menjaga lingkungan serta membantu reboisasi lahan yang belum tertanamkan. Hal ini serupa dengan unsur ekowisata pendapat dari Yoeti (2008 : 196) yaitu Ada kepedulian terhadap pelestarian Lingkungan Hidup.

Di dalam menerapkan unsur ekowisata sesuai dengan Yoeti (2008 : 196) bahwa terdapat unsur pendidikan. Gunung Putri dapat dijadikan sebagai sarana pendidikan, hal ini dapat terlihat pada saat penulis mendatangi Gunung Putri untuk penelitian. Penulis bertemu dengan mahasiswa dari salah satu perguruan. Mereka datang berkunjung dan meneliti tentang ekosistem di lingkungan yang berada di Gunung Putri

Di dalam unsur ekowisata terdapat unsur tentang Adanya keterlibatan penduduk lokal. Sama halnya yang terdapat di Gunung Putri bahwa masyarakat kampung gunung putri terlibat di dalam pelestarian maupun faktor ekonomi yang dilakukan didalam kesehariannya.

Di Gunung Putri Lembang terdapat beberapa kawasan atau area yang sangat diperhatikan juga pada keberlangsungan lingkungan dalam wisata berbasis Ekowisata yaitu :

\section{Offroad Area}

Dibagian Gunung Putri terdapat area untuk offroad dan motor cross. Namun bukan berarti merusak lahan yang berada di sekitar gunung putri. Para penghobi 
motor cross dan mobil offroad memiliki beberapa prosedur ataupun persyaratan yang harus di patuhi oleh penggunanya. Persyaratannya yaitu :

1. Tidak merusak tanaman atau menjaga pepohononan kecil tetap tegak (Tidak Jatuh) yang berada di sekitar jalur offroad

2. Diwajibkan untuk membawa tanaman berupa bibit pohon

3. Para penghobi offroad dan motor cross tidak mengambil jalur lain. Hanya menggunakan jalur yang di sediakan

4. Melibatkan penghobi untuk mengikuti program Safari Hutan. Dengan menanam pohon bersama

Dan dalam mendukung aksi wisata berbasis Ekowisata, pengelola akan memperbaiki jalur tersebut yang bertujuan penataan yang rapih dan menjaga konstruktur tanah. Dalam hal ini pengelola akan memberikan tambahan tarif seharga Rp. 10.000.

\section{Camping Area}

Camping Area adalah tempat favorit yang di gunakan para wisatawan untuk menghabiskan liburannya bersama teman - temannya maupun para komunitas penghobi. Serta menikmati indahnya matahari terbit di area kemping yaitu Tugu Gunung Putri.

Oleh sebab itu pengelola pun menghimbau juga bagi mereka yang mengadakan acara kemping di area Gunung Putri Lembang untuk menjaga lingkungan sekitar. Dengan cara : (1) tidak membuang buang sampah sembarangan (2) tidak boleh menebang pohon (3) tidak boleh membakar sampah non organik

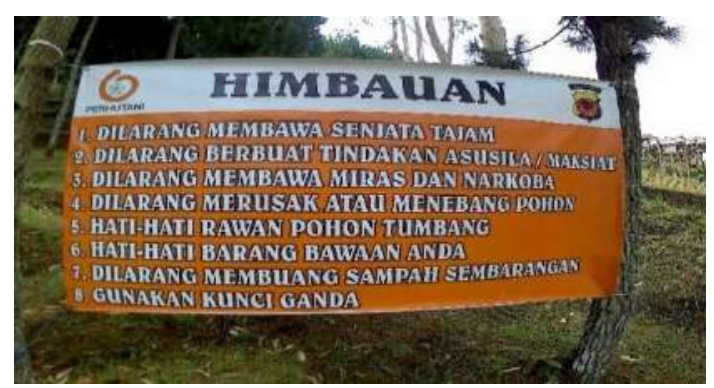

Gambar. 2

\section{(Himbauan Dari Pengelola)}

Pengelola pun memberikan Trash Bag untuk sampah bagi wisatawan yang berkemping, Trash Bag berfungsi supaya wisatawan tidak membuang sampah sembarangan. Ketika sampah itu sudah terkumpul dan dalam keadaan rapih. Para wisatawan dapat meninggalkan di tempat ataupun dibawa turun kembali serta mengembalikan ke petugas penjagaan. Ketika wisatawan meninggalkan sampah di ataspun maka sampah tersebut akan diambil oleh petugas lapangan.

Usaha pengelola baik dari Perhutani maupun masyarakat tersebut berupaya menerapkan wisata yang tidak mementingkan sisi objeknya melainkan juga dari sisi sadar lingkungan. Hal ini dapat terciptanya wisata berbasis Ekowisata.

Peran masyarakat sekitar lebih berperan penting dalam pembangunan serta pelestarian lingkungan di sekitar Gunung Putri Lembang. Masyarakat yang terlibat tersebut dapat memahami manfaat dari pelestarian lingkungan tersebut bagi sekitar 
Peneliti berhasil mengobservasi, mewawancarai dan mendapatkan studi dokumensi dari pihak yang terkait di dalam penelitian yang peneliti buat yaitu tentang pengembangan daya tarik wisata berbasis ekowisata di Gunung Putri Lembang Kabupaten Bandung Barat.

Gunung Putri adalah tempat dimana dapat di kembangkan menjadi wisata berbasis ekowisata. Di dalam memajukan wisata tersebut pengelola berusaha dalam memberikan pelayanan yang terbaik bagi para wisatawan dengan berpegang pada dasar Sapta Pesona berguna supaya wisatawan yang datang merasakan kenyaman serta ingin kembali lagi ke Gunung Putri. Pengelola berusaha memperbaiki kekurangan yang terjadi dari hasil masukan dari para wisatawan dan pengelola yang di bantu dari LMDH (Lembaga Masyarakat Desa Hutan) serta masyarakat sekitar berusaha untuk meningkatkan kedatangan jumlah wisatawan yang datang karena dari meningkatknya jumlah wisatawan tersebut dapat meningkatkan perekonomian khususnya masyarakat sekitar. Didalam prinsip, unsur dan juga tujuan dalam

Pengembangan Ekowisata di Gunung Putri sudah ada namun di dalam lapangan masih banyak kekurangan yang menjadikan pengembangan berbasis ekowisata belum berjalan dengan baik yaitu unsur pendidikan serta pro-aktif di dalam unsur ekowisata. Unsur pendidikan belum di terapkan oleh pengelola sementara itu rata-rata wisatawan mengunjungi ke lokasi tersebut hanya untuk melakukan rekreasi. Hanya beberapa wisatawan saja yang melakukan observasi saja itupun hanya dalam tugas yang diberikan. Sementara itu dalam unsur pro-aktif masih banyak wisatawan dan masyarakat di sekitar Gunung Putri yang belum adanya rasa memiliki. Banyak sampah yang yang di buang dimana saja tanpa mementingkan dampak buruk yang telah mereka lakukan. Pengelola sudah berusaha menghimbau kepada wisatawan dan masyarakat sekitar untuk sama-sama saling menjaga dan peduli lingkungan. Kemudian ditekankan juga bagi wisatawan untuk tidak mengganggu dan merusak tanaman khususnya tanaman pohon kecil karena itu dapat merusak pertumbuhan tanaman tersebut. Namun masih saja terjadi perusakan yang dilakukan oleh wisatawan yang tidak bertanggung jawab dengan alasan apapun.

Terdapat faktor-faktor yang mempengaruhi terjadinya Pengembangan Ekowisata di Gunung Putri. Faktor tersebut sangat berperan penting supaya berkembangya Gunung Putri dapat terwujud.

Wisatawan berperan penting untuk mendapatkan pendapatan terhadap berkembangnya Gunung Putri serta dari wisatawan dapat menambahkan penghasilan perekonomian msyarakat yang berjualan dan yang terlibat di dalam pengelolahan di Gunung Putri.

Industri Pariwisata berperan penting untuk memfasilitasi kebutuhan dari wisatawan yang ingin berkunjung ke Gunung Putri terutama terhadap wisatawan dari luar kota Bandung dapat membantu pertumbuhan wisatawan yang berkunjung ke Gunung Putri.

Industri Pariwisata ini memiliki aspek yang dapat membantu wisatawan untuk berkunjung seperti tersedianya Hotel atau Penginapan, Restaurant atau Cafe, Pusat Informasi wisata, dan atraksi wisata. Yang terjadi di lapangan bahwa di daerah sekitar Gunung Putri terdapat Banyak Hotel dan penginapan mulai dari Hotel dengan standar berbintang lima hingga kelas melati. Di daerah Gunung Putri banyak Restaurant ataupun Cafe yang di tawarkan oleh para pelaku usaha yang menawarkan makanan spesial atau khas dari daerahnya. Pusat informasi wisatawan 
di Gunung Putri sudah tersedia namun menurut penulis bahwa informasi yang diberikan oleh Pengelola kurang lengkap dan tidak terjangkau bagi para wisatawan yang ingin membaca informasi yang diberikan oleh Pengelola. Dan Atraksi wisata adalah sebuah pertunjukan yang paling inti dalam Pengembangan di daerah Gunung Putri. Dari atraksi ini pengunjung dapat merasakan keunggulan yang disajikan oleh pengelola.

Gunung Putri menawarkan Atraksi Wisata yaitu pemandangan yang indah yang berlatarkan kota bandung dan gunung-gunung yang menjulang di sekitar Gunung Putri kemudian Gunung Putri menyajikan peninggalan pada zaman dahulu yaitu terdapat sebuah Benteng Belanda hal ini dapat menjadikan wisatawan tertarik untuk berkunjung ke Gunung Putri. Pendukung Jasa Wisata ini adalah usaha yang tidak secara khusus menawarkan produk dan jasa namun seringkali bergantung pada wisatawan seperti penyedia jasa fotografi, jasa pemandu wisata, jasa penjualan BBM (Bahan Bakar Minyak). Di Gunung Putri ini untuk Jasa fotogari belum tersedia serta jasa pemandu wisata hal ini dapat penulis lihat bahwa kebanyakan wisatawan yang berkunjung sudah mempunyai camera sendiri, mulai dari camera handphone hingga camera DLSR (Digital Single Lens Reflex) sehingga peluang para penyedia jasa fotografi ini hanya sedikit dan untuk jasa pemandu wisatawan pengelola sendiri belum menyediakannya dikarenakan kekurangan SDM (Sumber Daya Manusia) dan ketika penulis perhatikan di lapangan bahwa para wisatawan yang berkunjung ke Gunung Putri umumnya ingin merasakan momen berpasangan serta dalam kelompok saja hal ini dapat terlihat untuk jasa pemandu wisata kurang di minati oleh wisatawan. Dan untuk jasa penjualan BBM (Bahan Bakar Minyak) di sekitar Gunung Putri belum tersedia. Harus berjalan beberapa ratus meter untuk membeli dan mengisi BBM ( Bahan Bakar Minyak).

Pemerintah sangat berperan aktif dalam Pengembangan daya tarik wisata berbasis Ekowisata di Gunung Putri Lembang. Pemerintah memeliki otoritas dalam pengaturan, penyediaan dan peruntukan berbagai infrastruktur yang terkait dengan kebutuhan pariwisata seperti menentukan arah yang dituju, penyediaan infrastruktur, keamanan dan kenyamanan di dalam kawasan. Pendampingan dalam promosi wisata, dan pengembangan sumber daya manusia. Ketika penulis melihat dan meninjau langsung di lapangannya bahwa untuk petunjuk arah yang menunjuk ke arah Gunung Putri belum tersedia. Untuk penunjuk arah pengelola yang di bantu dari LMDH (Lembaga Masyarakat Desa Hutan) berinisiatif membuatnya sendiri itupun dirasa hanya tulisan kecil yang menurut penulis tidak terlalu terlihat dari pinggir jalan utama ini dapat menjadikan wisatawan yang ingin berkunjung sedikit kebingungan ketika mencari tempat tersebut.

Untuk Infrastruktur sepeti jalan dan angkutan umum sudah tersedia namun untuk jalan masuk menuju Gunung Putri perlu di perbaiki dikarenakan masih terdapat jalan yang rusak dan berlubang hal ini dapat mengganggu kenyaman para wisatawan yang ingin mengunjungi tempat tersebut. Kemudian untuk kemanan dan kenyamanan di dalam lokasi masih sangat kurang terutama di dalam mendukung keselamatan para wisatawan yang ingin naik keatas gunung maupun berfoto, pagar yang juga sebagai penahan untuk berjalan hanyalah berupa bambu yang kecil hal ini dapat membahayakan ketika terjadi salah satu bambu yang sudah rapuh dan lapuk kemudian ketika berada di sesi foto tidak terdapat pagar pengaman ini juga dapat menjadikan wisatawan kurang nyaman dan takut terjadi hal yang tidak diinginkan ketika berfoto. Pemerintah juga harus meninjau langsung 
pengembangan di dalam sumber daya manusianya karena ketika pemerintah langsung turun dan meninjau, pemerintah akan menemukan kendala yang terjadi di dalamnya. Penulis belum melihat keterlibatan secara langsung dari pemerintah. Penulis mengetahuinya info tersebut pada saat penulis mewawancari pengelola. Masyarakat Lokal adalah penduduk yang bermukim di kawasan wisata, menjadi salah satu pemain kunci dalam parwisata. Sesungguhnya merekalah yang akan menyediakan sebagian besar atraksi sekaligus menentukan kualitas produk wisata seperti pengelolaan lahan pertanian, upacara adat, kerajinan tangan dan kebersihan yang dapat memberikan daya tarik bagi pariwisata.

Penulis melihat langsung dari fasilitas yang di berikan terhadap Pemerintah Desa yaitu berupa panggung dan stand kesenian. Panggung dan Stand kesenian ini rencananya akan di libatkan dari para pelaku seni serta ibu-ibu PKK dari RW 01 sampai RW 10. Pihak Desa berharap dapat mengembangkan kembali Kesenian khas tradisional khususnya didaerah Desa Jayagiri dan kerajinan tangan yang berada di masing-masing RW dengan ciri khas yang berbeda. Hal ini dapat membuat tertarik para wisatawan berkunjung dan merasakan kesenian kebudayaan dari masyarakat lokal. Lembaga Swadaya masyarakat di Gunung Putri Lembang terdapat LMDH atau di sebut Lembaga Masyarakat Desa Hutan ini sangat penting dan berguna untuk menjadi jembatan penghubung antara Masyarakat, Desa dan Hutan dan juga dapat menjadi titik pendapat dari masing-masing demi mewujudkan terciptanya pengembangan daya tari wisata berbasis ekowisata di Gunung Putri Lembang Kabupaten Bandung Barat.

Program pengembangan ekowisata, program ini dapat menjadi acuan pengembangan daya tarik wisata berbasis ekowisata di Gunung Putri dapat terwujud. program tersebut sudah di terapkan oleh pengelola seperti penghimbauan melalui spanduk yang diharapkan dapat menghambat dan mengurangi terjadinya kerusakan ataupun pencemaran pada lingkungan sekitar dan memberikan himbauan pada masyarakat juga untuk sadar dan peran serta dalam menjaga lingkungannya hal ini dapat mendukung pengembangan dari Gunung Putri tersebut. Menawarkan pengalaman yang positif bagi wisatawan dan masyarakat di dalam aktivitas dan konservasi daya tarik wisata. Hasil tersebut dapat menjadikan kesadaran wisatawan akan bisa menjaga, memelihara dan juga melestarikan alam serta dari pihak masyarakat diharapkan dapat turun langsung menjaga dan melestarikan alam, fungsi tersebut dapat memberikan dampak positif terhadap lingkungan dan lingkungan pun akan memberikan hasilnya bagi wisatawan dan masyarakat.

\section{SIMPULAN}

Berdasarkan analisis terhadap pengembangan daya tarik wisata secara keseluruhan memenuhi kriteria - kriteria berkembangnya daya tarik wisata berbasis ekowisata hanya saja di dalam fasilitas jauh dari kata sempurna masih banyak fasilitas yang harus benahi dan ditambah dalam mendukung kenyamanan bagi wisatawan

Berdasarkan analisis wisata berbasis ekowisata bahwa lokasi tersebut belum mengandung unsur pro aktif dan pendidikan. Kurangnya kesadaran wisatawan dalam menjaga lokasi wisata tersebut masih di temukan sampah yang di buang begitu saja dimana-mana. Masyarakat sekitar yang kurang peduli terhadap lingkungan di area sekitar wisata. Unsur pendidikan pada wisatawan dan 
masyarakat lokal berguna untuk turut sadar akan manfaat dan fungsi lingkungan bagi sekitarnya.

Berdasarkan faktor-faktor yang mempengaruhi pengembangan ekowisata terdapat wisatawan, Industri Pariwisata, pendukung jasa wisata, Pemerintah, masyarakat lokal dan lembaga swadaya masyarakat lokal terdapat beberapa diantaranya yang belum mendukung dengan maksimal yaitu Pemerintah dan pendukung jasa wisata.

Berdasarkan analisis dari program pengembangan ekowisata terdapat beberapa yang sudah terlaksana seperti :

1. Mengurangi dampak kerusakan pada lingkungan yaitu dengan melakukan reboisasi di sekitar lahan Gunung Putri yang kosong

2. Melibatkan masyarakat lokal yaitu dengan membentuk lembaga masyarakat Desa Hutan, melibatkan pelaku seni untuk turut andil dalam mempromosikan dan mengenalkan budaya daerahnya kepada wisatawan dan mempekerjakan masyarakat lokal pengangguran dengan menyediakan tempat untuk mereka usaha

3. Mengenalkan wisatawan tentang ekowisata, pada dasarnya pengenalan tentang ekowisata pada wisatawan di Gunung Putri belum berjalan maksimal. Sedikit dari wisatawan mencari tahu sendiri tentang ekowisata. dan dari pihak pengelola pun belum menerapkan pengenalan ekowisata terhadap wisatawan.

Demi mendukung pengembangan daya tarik wisata berbasis ekowisata di Gunung

Putri Lembang berjalan maka dapat menerapkan dengan konsep ekowisata

Tabel 1

Operasional Variable

\begin{tabular}{|c|c|c|c|}
\hline No & Variable & Sub variable & Indikator \\
\hline 1. & $\begin{array}{c}\text { Aspek } \\
\text { Pengembangan }\end{array}$ & $\begin{array}{l}\text { Memajukan } \\
\text { Memperbaiki } \\
\text { Meningkatkan }\end{array}$ & $\begin{array}{l}\text { 1. Daya tarik wisata } \\
\text { 2. Perekonomian penduduk lokal } \\
\text { 3. Kesejahteraan penduduk lokal } \\
\text { 1. Fasilitas } \\
\text { 2. Pelayanan terhadap wisatawan } \\
\text { 3. Program kerja daya tarik wisata } \\
\text { 1. Kenyamanan } \\
\text { 2. keamanan } \\
\text { 3. kepedulian terhadap lingkungan } \\
\text { 4. kesadaran terhadap lingkungan }\end{array}$ \\
\hline 2. & $\begin{array}{c}\text { Aspek } \\
\text { Ekowisata }\end{array}$ & $\begin{array}{l}\text { Ekonomi } \\
\text { Sosial }\end{array}$ & $\begin{array}{l}\text { 1. Tambahan penghasilan dari ekowisata } \\
\text { 2. Mendorong bisnis wisata } \\
\text { 3. Ditribusi manfaat dan kesejahteraan } \\
\text { 4. Perbaikan mutu kehidupan penduduk lokal } \\
\text { 1. Penduduk lokal } \\
\text { 2. Pemerintah } \\
\text { 3. Kelompok Masyarakat nirlaba (LSM atau } \\
\text { 4. Sektor swasta } \\
\text { 5. Wisatawan } \\
\text { 6. Pihak lain yang tidak secara langsung terkait } \\
\text { 1. Pengan ekowisata } \\
\text { 2. Peningkatan kesadaran konservasi } \\
\text { 3. Pengembangan kesadaran konservasi } \\
\text { 3. lingkungan penduduk lokal } \\
\text { 3. Pesadaran konservasi }\end{array}$ \\
\hline
\end{tabular}


Tabel 2

Stakeholder Tinjauan Teori Dengan Kenyataan Yang Terjadi di Gunung Putri Lembang Kabupaten Bandung Barat

\begin{tabular}{|c|c|c|c|c|c|}
\hline No & Program & \multicolumn{2}{|r|}{ Tinjauan Teori } & \multicolumn{2}{|r|}{ Fakta Lapangan di Gunung Putri } \\
\hline \multirow[t]{4}{*}{1.} & \multirow[t]{4}{*}{$\begin{array}{l}\text { Mengurangi } \\
\text { dampak } \\
\text { kerusakan pada } \\
\text { lingkungan }\end{array}$} & & $\begin{array}{l}\text { Memberlakukan } \\
\text { sistem reboisasi }\end{array}$ & & $\begin{array}{l}\text { Pengelola sudah menerapkan sistem } \\
\text { reboisasi di punggung Gunung Putri } \\
\text { dan area sekitarnya }\end{array}$ \\
\hline & & 2 & $\begin{array}{l}\text { Menjaga dan } \\
\text { melestarikan } \\
\text { lingkungan sekitar }\end{array}$ & 2. & $\begin{array}{l}\text { Dalam menjaga dan melestarikan } \\
\text { lingkungan sekitar pengelola setiap } \\
\text { harinya selalu memantau }\end{array}$ \\
\hline & & 3 & $\begin{array}{l}\text { Tidak membuang } \\
\text { sampah } \\
\text { sembarangan }\end{array}$ & & $\begin{array}{l}\text { Pengelola selalu memberikan } \\
\text { himbauan pada wisatwan khususnya } \\
\text { untuk tidak membuang sampah } \\
\text { sembarangan dan didukung dengan } \\
\text { cara memberikan trash bag kepada } \\
\text { wisatawan supaya area Gunung } \\
\text { Putri tetap terjaga }\end{array}$ \\
\hline & & 4 & $\begin{array}{l}\text { Tidak merusak } \\
\text { tanaman yang } \\
\text { berada di } \\
\text { lingkungan sekitar }\end{array}$ & & $\begin{array}{l}\text { Dalam menjaga supaya tanaman } \\
\text { yang berada disekitar Gunung Putri. } \\
\text { Pengelola memberikan himbauan } \\
\text { melalui lisan yaitu pada saat } \\
\text { wisatawan berkunjung serta tulisan } \\
\text { melalui plang yang berada di sekitar } \\
\text { area Gunung Putri }\end{array}$ \\
\hline \multirow[t]{4}{*}{2.} & \multirow[t]{4}{*}{$\begin{array}{l}\text { Melibatkan } \\
\text { Masyarakat } \\
\text { Lokal }\end{array}$} & 5 & $\begin{array}{l}\text { Sosialisai tentang } \\
\text { manfaat hutan dan } \\
\text { lingkungan } \\
\text { sekitarnya }\end{array}$ & & $\begin{array}{l}\text { Dalam sosialisasi pada masyarakat } \\
\text { sekitar tentang manfaat hutan } \\
\text { dengan cara prakttik langsung ke } \\
\text { lapangan karena sebagian besar } \\
\text { masyarakat disekitar bekerja } \\
\text { sebagai petani sayuran dan juga } \\
\text { peternak sapi yang menanam di area } \\
\text { dekat Gunung Putri }\end{array}$ \\
\hline & & & $\begin{array}{l}\text { Sosialisasi tentang } \\
\text { tidak } \\
\text { memperhatikan dan } \\
\text { melestarikan } \\
\text { lingkungan } \\
\text { sekitarnya }\end{array}$ & & $\begin{array}{l}\text { Dalam Sosialisai tentang tidak } \\
\text { memperhatikan dan melestarikan } \\
\text { lingkungan di sekitar pengelola } \\
\text { memberikan arahan pada saat warga } \\
\text { mengadakan gotong royong yang } \\
\text { rutin bersama pengelola }\end{array}$ \\
\hline & & 8. & $\begin{array}{l}\text { Terjun langsung } \\
\text { dalam menjaga dan } \\
\text { melestarikan } \\
\text { lingkungan sekitar }\end{array}$ & & $\begin{array}{l}\text { Masyarakat sekitar mempraktikan } \\
\text { peduli terhadap lingkungan dengan } \\
\text { selalu menjaga kebersihan di area } \\
\text { jalan menuju Gunung Putri dengan } \\
\text { selalu mengambil sampah yang } \\
\text { berserakan dan menyimpannya } \\
\text { ditempat yang sudah di sediakan } \\
\text { Dalam melibatkan para pelaku.seni. }\end{array}$ \\
\hline & & & $\begin{array}{l}\text { para pelaku seni } \\
\text { untuk mengenalkan } \\
\text { kebudayaan di } \\
\text { daerahnya untuk } \\
\text { mengenalkan pada } \\
\text { wisatawan }\end{array}$ & & $\begin{array}{l}\text { Pemerintah Desa Jayagiri } \\
\text { melibatkan warga di desanya } \\
\text { dengan cara seminggu sekali } \\
\text { bergiliran pada setiap RW untuk } \\
\text { menunjukan atraksi kesenian yang } \\
\text { berada di sekitarnya dan melibatkan } \\
\text { ibu - ibu PKK di desanya untuk } \\
\text { mengenalkan dan menjual hasil } \\
\text { kerajinan tangan khas daerahnya }\end{array}$ \\
\hline
\end{tabular}




\begin{tabular}{|c|c|c|c|c|c|}
\hline 3. & $\begin{array}{l}\text { Mengenalkan } \\
\text { wisatawan } \\
\text { tentang } \\
\text { ekowisata }\end{array}$ & 7. & 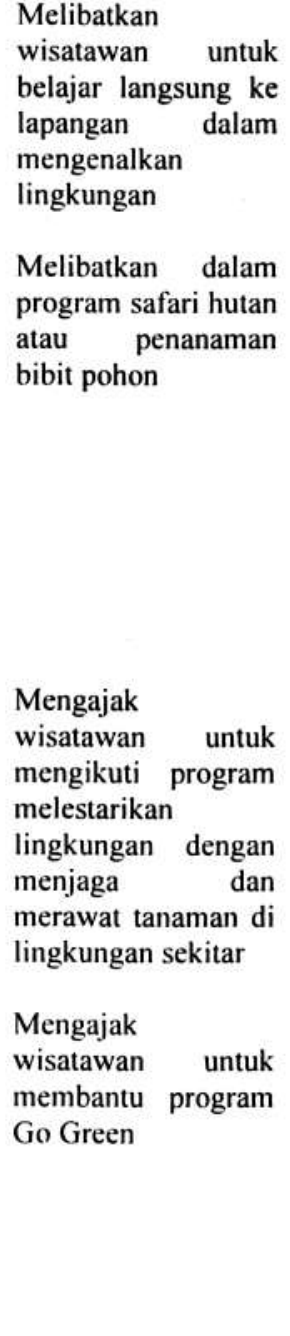 & 3. & 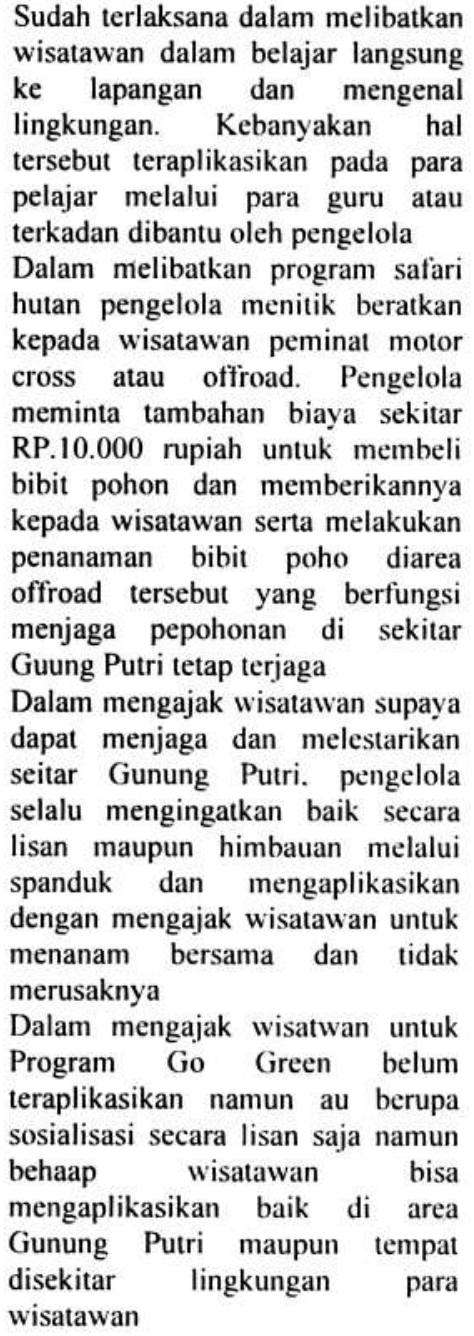 \\
\hline
\end{tabular}

Sumber : Data diolah Penulis 2018

\section{DAFTAR PUSTAKA}

Athea, K. (2013). Ensiklopedia Mini Manajemen Kepariwisataan. Bandung: CV Angkasa.

Fandeli, C. (2004). Analisis mengenai dampak lingkungan. Prinsip dasar dalam pembangunan. Yogyakarta: Liberty Offset.

Hakim, L. (2004). Dasar-Dasar Ekowisata. Jawa Timur: Bayumedia Publishing.

Kusmayadi . (2004). Statistika Pariwisata Deskriptif. Jakarta: PT. Gramedia Pustaka Utama.

Nugroho, I. (2011). Ekowisata dan Pembangunan berkelanjutan. Yogyakarta: PT Pustaka Pelajar.

Sugiyono. (2007). Metode Penelitian Kuantitatif Kualitatif dan R\&D. Bandung: CV Alfabeta. 
Sugiyono. (2008). Metode Penelitian Kunatitatif Kualitatif dan R\&D. Bandung: CV Alfabeta.

Peraturan Menteri Dalam Negeri Nomor 33 Tahun 2009 Tentang Pedoman Pengembangan Ekowisata di Daerah

Poerwadarminta, W.J.S. (2002). Kamus Umum Bahasa Indonesia. Jakarta: Balai Pustaka.

Riyanti, E. (2015). Pengembangan Atraksi Berbasis Ekowisata di Desa Wisata Lamajang Kabupaten Bandung. Bandung: STIEPAR Yapari-Aktripa.

Setianingsih,W. (2006) Pengembangan Obyek Wisata Serulingmas Sebagai Salah Satu Sumber Pendapatan Asli Daerah Kabupaten Banjarnegara. Semarang: Universitas Negeri Semarang

Undang-Undang RI Nomor 10 Tahun 2009. Tentang Kepariwisataan

Undang-Undang RI Kepariwisataan Nomor 11 Tahun 2010 Tentang Cagar Budaya

Warpani, Suwardjoko P \& Warpani, Indira P. (2007). Pariwisata dalam Tata Ruang Wilayah. Bandung: ITB

Yoeti, Oka, A. (2008). Perencanaaan dan Pengembangan Pariwisata. Jakarta: Pradaya Pratama.

Yoeti, Oka, A. (2008). Ekonomi Pariwisata: Introduksi, Informasi, dan Implementasi . Jakarta: Penerbit Kompas.

\section{Internet:}

Ekowisata. http:// www. ekowisata.info/definisi_ekowisata. Html diakses pada 25 okt 2011 